\title{
Quetiapine-related Rabbit syndrome in a Patient with Bipolar Depression and Treated with Olanzapine-fluoxetine Combination
}

\author{
H Belli, M Akbudak, ZE Bal
}

\begin{abstract}
Rabbit syndrome (RS) is an extrapyramidal side-effect which is described as a variant of tardive dyskinesia. Rabbit syndrome is characterized by rapid, rythmic orofacial movements, often accompanied by lip sounds. This movement disorder may be associated with either typical or atypical antipsychotic agents. The index case presented to our clinic with the complaints of bipolar depression. In addition to valproate, quetiapine was started with the dose of $50 \mathrm{mg}$ per day, which was increased to $300 \mathrm{mg}$ per day within two weeks for depression. After 12 weeks of treatment with quetiapine $300 \mathrm{mg} /$ day, she developed RS. Quetiapine was reduced gradually and stopped. Olanzapine $5 \mathrm{mg}$ per day and fluoxetine $20 \mathrm{mg}$ per day were added for depression. After four weeks of the olanzapine and fluoxetine treatment, her symptoms of RS disappeared. A state of dopaminergic hypersensitivity may be postulated for the underlying mechanism of quetiapine-related RS. The observed improvement in the patient's disturbances following fluoxetine introduction may further play a role in the improvement of RS and depression symptoms.
\end{abstract}

Keywords: Bipolar depression, fluoxetine, olanzapine, quetiapine

\section{El síndrome de Conejo Relacionado con la Quetiapina en un Paciente con Depresión Tratado con una Combinación de Olanzapina y Fluoxetina}

\author{
H Belli, M Akbudak, ZE Bal
}

\begin{abstract}
RESUMEN
El síndrome del conejo $(S C)$ es un efecto secundario extrapiramidal que se describe como una variante de la discinesia tardía. El síndrome del conejo se caracteriza por movimientos orofaciales, rápidos y ritmicos, a menudo acompañados de sonidos de los labios. Este trastorno del movimiento puede asociarse con agentes antipsicóticos típicos o atípicos. El caso índice acudió a nuestra clínica con quejas de depresión bipolar. Además del valproato, la quetiapina fue iniciada con una dosis de $50 \mathrm{mg}$ por día, que fue aumentada a $300 \mathrm{mg}$ por día, dentro de dos semanas para la depresión. Después de 12 semanas de tratamiento con $300 \mathrm{mg} /$ día de quetiapina, la paciente desarrolló el SC. La quetiapina fue reducida gradualmente y terminada. Una dosis de $5 \mathrm{mg} /$ día de olanzapina, y $20 \mathrm{mg}$ al día de fluoxetina fueron agregados para la depresión. Después de cuatro semanas del tratamiento con olanzapina y fluoxetina, desaparecieron los síntomas de SC. Un estado de hipersensibilidad dopaminérgica puede ser atribuido al mecanismo subyacente del SC relacionado con la quetiapina. La mejoría observada en relación con los trastornos del paciente tras la introducción de la fluoxetina puede además desempeñar un papel en la mejoría del SC y los sintomas de la depresión.
\end{abstract}

Palabras claves: Depresión bipolar, fluoxetina, olanzapina, quetiapina

West Indian Med J 2017; 66 (1): 171

From: Department of Psychiatry, Bagcilar Education and Research Hospital, Istanbul, Turkey.

Correspondence: Dr H Belli, Department of Psychiatry, Bagcilar Education and Research Hospital, Istanbul, Turkey. Fax: +90 21244040 00; email: hasan.belli@hotmail.com

\section{INTRODUCTION}

Rabbit syndrome (RS) is an extrapyramidal side-effect which is described as a variant of tardive dyskinesia (TD). However, there are several authors who describe it as a dystonic variant. Rabbit syndrome is characterized by rapid, rhythmic orofacial 
movements, often accompanied by lip sounds. This movement disorder may be associated with either typical or atypical antipsychotic agents as suggested by previous papers (1).

In the present paper, we describe the case of quetiapinerelated RS in a female patient suffering from bipolar depression who remitted as a result of olanzapine and fluoxetine combination therapy.

\section{CASE REPORT}

Ms P, a female, 58 years old, suffered from bipolar I for 32 years. She had a stable mental status for more than three years. She was treated with valproate $1000 \mathrm{mg}$ per day for four years. She visited our clinic with the complaints of bipolar depression. A screen for symptoms of major depression revealed that she had hopelessness, low energy, anhedonia, poor appetite, poor concentration, a strong sense of guilt and insomnia. She had become extremely withdrawn from her social relations. The patient had been treated with the same dose of valproate over a long-time. In addition to valproate, quetiapine was started with the dose of $50 \mathrm{mg}$ per day and the dose was increased to $300 \mathrm{mg}$ per day within two weeks for depression symptoms. After 10 weeks of treatment with quetiapine, we observed a significant reduction in depression symptoms. After 12 weeks of treatment with quetiapine $300 \mathrm{mg} /$ day, she developed involuntary movements of the lips, vertical fine and rapid movements with a popping sound. However, akathisia and restlessness were also noted. Results of neurological, general physical examination, and laboratory investigation, including: blood chemistry, thyroid function test, follicle-stimulating hormone (FSH), luteinising hormone (LH), creatine phosphokinase (CPK), valproate level, liver and renal function were normal. The patient then had an electroencephalogram (EEG) and magnetic resonance imaging (MRI) and result of these tests were within normal limits. Quetiapine was reduced gradually and stopped. Olanzapine $5 \mathrm{mg}$ per day and fluoxetine $20 \mathrm{mg}$ per day were added for depression. After four weeks on the olanzapine and fluoxetine treatment, her symptoms of RS disappeared. Akathisia and restlessness also improved. Three months after combination treatment with olanzapine $5 \mathrm{mg}$ per day, $20 \mathrm{mg}$ fluoxetine per day and valproate 1000 $\mathrm{mg}$ per day, she remained in full remission from her RS, depression and manic symptoms.

\section{DISCUSSION}

It has been postulated that the underlying mechanism of RS is super-sensitivity of the dopamine receptors, possibly due to an underlying predisposition (2). Rabbit syndrome is similar to the mild oral form of tardive dyskinesia (3). The mechanism of quetiapine-related RS is unclear. It has been demonstrated that atypical antipsychotics including: risperidone, clozapine and aripiprazole may increase RS risk in the literature (4). Tardive dyskinesia related to quetiapine has been demonstrated also in several cases (5). A state of dopaminergic hypersensitivity may be postulated as the underlying mechanism of quetiapine-related RS. Nishiyama et al postulated the underlying mechanism of RS is a state of cholinergic hypofunction due to dopaminergic hypersensitivity in the basal ganglia (6). However, our case had several risk factors for RS, including: old age, being female (4) and diagnosis of mood disorder (7).

It is possible to hypothesize that properties of quetiapinerelated RS may be due to quetiapine combined action on both the cholinergic and the dopaminergic receptors. The combined cholinergic and the dopaminergic transmission due to olanzapine and serotonergic transmission due to fluoxetine, may explain the positive outcome observed in this case. In addition, this patient has several risk factors related to RS and extrapyramidal side effects such as older age, being female and a bipolar diagnosis. Therefore, low dose olanzapine could cause RS or other side effects. However, the patient had been treated with olanzapine for only three months. This movement disorder can still occur if the patient who has several risk factors for TD and RS continue this treatment. In fact, the observed improvement in the patient's disturbances following fluoxetine introduction may have played a further role in the improvement of RS and depression symptoms.

The observation from this case suggests that there is a possible risk of RS with quetiapine treatment, especially in high-risk patients. The present paper supports the notion that olanzapine and fluoxetine combination may be effective in the treatment of RS and depressive symptoms in patients with bipolar disorder.

\section{REFERENCES}

1. Schwartz M, Hocherman S. Antipsychotic-induced rabbit syndrome: epidemiology, management and pathophysiology. CNS drugs 2004; 18: $213-$ 20.

2. Durst R, Katz G, Zislin J, Raskin S, Kalman I. Rabbit syndrome treated with olanzapine. Br J Psychiatry 2000; 176: 193-6.

3. Levin T, Heresco-Levy U. Risperidone-induced rabbit syndrome: an unusual movement disorder caused by an atypical antipsychotic. Eur Neuropsychopharmacol 1999; 9: 137-9.

4. Catena Dell'osso M, Fagiolini A, Ducci F, Masalehdan A, Ciapparelli A, Frank E. Newer antipsychotics and the rabbit syndrome. Clin Pract Epidemiol Ment Health 2007; 3: 6.

5. Sharma V. Treatment-emergent tardive dyskinesia with quetiapine in mood disorders. J Clin Psychopharmacol 2003; 23: 415-7.

6. Nishiyama K, Masuda N, Kurisaki H. A case of rabbit syndrome-its unique pharmacological feature. Rinsho Shinkeigaku 1993; 33: 663-5.

7. Eren I, Ozcankaya R, Altınyazar V. Risperidone-induced rabbit syndrome in mood disorder. Eur Psychiatr 2004; 19: 452-3. 